\title{
Participation, Co-Creation, and Public Space
}

\author{
Marcus Foth \\ Queensland University of Technology, Australia \\ Urban Informatics \\ m.foth@qut.edu.au
}

\begin{abstract}
A central notion in urban design, urban interaction design, and placemaking is the user of public space, the occupant, resident, citizen, bystander, passer-by, explorer, or flâneur. When the field of human-computer interaction $(\mathrm{HCl})$ first emerged, the disciplines that represented the "human" aspects of $\mathrm{HCl}$ included behavioural psychology, cognitive science and human factors engineering. This situatedness begs the question whether the "user" requires different contextualisations beyond the immediate and traditional $\mathrm{HCl}$ concerns of the technical interface, that is, beyond usability.

This article aims to illustrate the need for placemakers and urban interaction designers to be transdisciplinary and agile in order to navigate different levels of granularity. This article seeks to practice granular agile thinking by introducing five possible ways to think about the "urban user" and the implications that follow: the user as city resident; the user as consumer of city services; the user as participant in the city's community consultations; the user as co-creator in a collaborative approach to citymaking, and finally; the user re-thought as part of a much larger and more complex ecosystem of more-than-human worlds and of cohabitation - a process that decentres the human in the design of collaborative cities.
\end{abstract}

Keywords: participation, urban interaction design, human-computer interaction, public space, placemaking

To cite this article:

Foth, M. (2017). Participation, Co-Creation, and Public Space. The Journal of Public Space, 2(4), 21 36, DOI: 10.5204/jps.v2i4.139

This article has been peer-reviewed and accepted for publication in The Journal of Public Space. Please see the Editorial Policies under the 'About' section of the journal website for further information.

This work is licensed under a Creative Commons Attribution - Non Commercial 4.0 International License https://creativecommons.org/licenses/by-nc/4.0/ 
A central notion in urban design, urban interaction design, and placemaking is the user of public space, the occupant, resident, citizen, bystander, passer-by, explorer, or flâneur. When the field of human-computer interaction $(\mathrm{HCl})$ first emerged, the disciplines that represented the "human" aspects of $\mathrm{HCl}$ included behavioural psychology, cognitive science and human factors engineering. Over time, the field has evolved to take into account both new technological developments and new usage practices (Bannon, 1992). Harrison, Tatar, and Sengers (2007) trace the development of $\mathrm{HCl}$ and distinguish three distinct paradigms: human factors; classical cognitivism / information processing, and; phenomenologically situated studies. With the scope of $\mathrm{HCl}$ widening in the wake of the introduction of ubiquitous computing (Foth, Forlano, Satchell, \& Gibbs, 20 I I), urban interaction design emerged as a subfield of $\mathrm{HCl}$ situated in cities and associated urban, suburban, peri-urban environments. This situatedness begs the question whether the "user" requires different contextualisations beyond the immediate and traditional $\mathrm{HCl}$ concerns of the technical interface, that is, beyond usability (Huh, Ackerman, Erickson, Harrison, \& Sengers, 2007).

This article aims to illustrate the need for placemakers and urban interaction designers to be transdisciplinary and agile in order to navigate different levels of granularity. This article seeks to practice granular agile thinking by introducing five possible ways to think about the "urban user" and the implications that follow: the user as city resident; the user as consumer of city services; the user as participant in the city's community consultations; the user as co-creator in a collaborative approach to citymaking, and finally; the user rethought as part of a much larger and more complex ecosystem of more-than-human worlds and of cohabitation - a process that decentres the human in the design of collaborative cities (Forlano, 2016). Table xx shows the first four development stages of this relationship between cities and people living in cities.

\begin{tabular}{l|l|l} 
& City Government & Citizens \\
\hline Cities $\mathbf{4 . 0}$ & Collaborator & Co-Creator \\
\hline Cities $\mathbf{3 . 0}$ & Facilitator & Participants \\
\hline Cities $\mathbf{2 . 0}$ & Service Provider & Consumers \\
\hline Cities $\mathbf{I . 0}$ & Administrator & Residents \\
\hline
\end{tabular}

Table I: The evolution of the relationship between city governments and citizens

In the following we will look at each stage one by one, however, we also want to use this journey to practice how to keep the bigger picture in mind. We will do so by explicating the increasing scale, scope, and granularity at play on each level. The main point to take away is that not any one level is right or more important than the other; rather, the ability to move attention in an agile manner across a three dimensional "T model." The original metaphor of a "T-shaped" skills profile (Guest, I99I) aligns the X axis with transdisciplinary breadth of knowledge. We stressed the significance of transdisciplinarity 
in the book's first section on Foundations. The $Y$ axis stands for depth of expertise, which we are developing further as the book unfolds. However, this section then introduces a $Z$ axis, which symbolises the level of conceptual granularity starting from the lower layers of people, streets, and public space; middle layers of urban commons, community groups, and neighbourhoods; to higher layers of abstraction, influence and reach, such as questions of space ownership, city governance, agency, and representation. Let us begin by looking at the first layer: the user conceived as urban dweller and city resident.

\section{City Residents}

The basic understanding in urban interaction design conceives of users as city residents. With the advent of ubiquitous computing (Rogers, 2009), early contributions influenced how the emerging fields of urban computing and urban interaction design approached the "user in the city." Examples include the Digital Cities workshop series that started in 1999 in Kyoto, Japan (Ishida \& Isbister, 2000), the 2006 special issue of Computer, "Urban Computing: Navigating Space and Context" guest edited by Shklovski and Chang (2006), and the 2007 special issue of Pervasive Computing, "Urban Computing" guest edited by Kindberg, Chalmers, \& Paulos (2007).

The "Familiar Stranger" project by Paulos and Goodman (2004) provides a great example of an early urban computing / urban interaction design study, which sought to re-think the notion of "user" in a city. Rather than being concerned with any immediate form of technology usage, the point of departure for this inquiry may have been to think about people "using" the city: What do they do? City residents move about from A to B. They navigate, negotiate, and traverse urban environments. They pause at traffic lights, wait at bus stops, rest at cafés, perhaps meet someone familiar on the street and stop for a chat. However, the number of people inhabiting cities makes it impractical to formally greet and introduce yourself to each and every one. Although people living in cities may take this normative behaviour for granted, it becomes more apparent when we leave the buzz of the city behind and for instance, embark on a hiking trip through the woods or mountains in a more deserted part of the world. When we then encounter another human being, even if we do not know them personally, we usually greet them, and we may even stop for a quick chat. The population density of cities prevents such behaviour from being practical.

Paulos and Goodman revisited the social phenomenon dubbed "Familiar Stranger" by Stanley Milgram (1992 [1972]). Milgram described familiar strangers to be people we see in the city and recognise, for example, on public transport every morning on the way to work. However, we choose to not interact with this person. This is due to the urban cultural norm of maintaining "civil inattention" - another social phenomenon characteristic for city living described by sociologist Erving Goffman (2009 [1972]). It is these cross-disciplinary links to social science studies and insights - such as human geography, cultural studies, urban sociology - that are vital for urban interaction design in a similar way to how cognitive science, behavioural psychology and human factors were quintessential to the emergence of the field of $\mathrm{HCl}$.

Designers are not just interested in producing new knowledge and understandings, but also in translating this new understanding into actionable knowledge to inform and trial 
new designs. In their study, Paulos and Goodman came up with several designs "for both a personal, body-worn, wireless device and a mobile phone based application that extend the Familiar Stranger relationship while respecting the delicate, yet important, constraints of our feelings and affinities with strangers in public places" (2004, p. 223).

The widespread adoption of mobile phones and the ability to develop and deploy location-based applications triggered a twofold interest in urban interaction design studies such as the "Familiar Stranger." First, it gave the field of interaction design an ability to create interventions that explored new terrain at the intersection of the physical and digital city - what some referred to as hybrid space or net localities (Bilandzic \& Foth, 2012; Gordon \& de Souza e Silva, 20I I; Seeburger, Foth, \& Tjondronegoro, 20I5). Second, it also marked the renunciation of cyberspace as distinct and removed from the real world due to the growing interest by geographers and sociologists in digital and locative media applications and by media and communication studies scholars in place and locality - what has been termed "the spatial turn" (Beer \& Burrows, 2007; Graham, 2004; Hardey, 2007; Scharl \& Tochtermann, 2007).

Despite being literally situated outside what used to be the conventional spatial areas of interest in $\mathrm{HCl}$ - the professional environment of the office and the domestic environment of the home - cities do offer plenty of use cases for urban interaction design. So in addition to the exploration of sociological concepts such as familiar strangers and civil inattention, the traditional focus on use and usability continued to be adopted. An example of this is the use of wifi and other mobile and wireless networks in the city, which has been explored in various studies at the intersection of interaction design, urban sociology, and media and communication studies. For example, Forlano (2009) conducted an extensive network ethnography of community wireless networks in order to better understand their role in reconfiguring cities. Inspired by the observations (including video recordings) made by William $\mathrm{H}$. Whyte for his book The Social Life of Small Urban Spaces (1980), Hampton, Livio, and Sessions (2010) studied wifi use in urban public spaces. The provision of a city-wide public wifi network has been pioneered in Oulu, Finland. The rollout was part of one of the first ubiquitous computing test beds and also included a set of public interactive displays both indoors and outdoors across the city (Ylipulli, Suopajärvi, Ojala, Kostakos, \& Kukka, 2014).

\section{Consumers}

Interaction designers do not always have the luxury and privilege to conduct independent design research that provides the flexibility to conduct an inquiry led by social and cultural issues and questions. We are often asked to provide our expertise and skills as a service to clients with specific needs and requirements. In the context of cities, the client may be a city administration or local government, and it is useful to create an awareness of the relationships, status of power and agency, and circles of influence at stake in any one project. As a way to make sense of the communicative ecology (Hearn \& Foth, 2007) or ecosystem of partners, stakeholder groups, the rich picture can be an effective tool to map and make sense of this often dense space (Monk \& Howard, 1998). When considering the triad of designer, client and user, it is essential to be sensitive to differences between the way a client conceives of their user base and the picture 
emerging from user research the designer conducts (Hearn \& Foth, 2005). Let us assume in the context of cities that the client is a local government administration, more specifically, the public transport department responsible for ensuring mobility across the city's network of buses, trains, trams and ferries. They may be interested in exploring how GPS enabled mobile phones and journey planner apps can improve the service experience of their user, that is, customer base: public transport passengers as consumers of transport services. For example, a reasonable view may be that passengers want to reach their destination quicker using fewer interchanges and shorter routes.

An urban interaction designer having previously studied the fine granularity at the level of users as city residents would bring to the task a rich understanding of the socio-cultural nuances at play in urban interactions. The challenge is to master a balancing act that requires the artful integration of knowledge and insights about people at different levels of granularity. In the context of public transport passengers, users can be conceived at the street level: a person riding a bus or train, or in fact, user personas characteristic of diverse patterns of behaviour displayed by different people using public transport (Blomkvist, 2002). They can also be conceived at the bird's eye view level as a ratio of public transport passengers across different modes of transport available in the city. Although the client may initially not require or be interested in the level of rich detail, nuance and fine granularity for their immediate requirements - to manage and administer the transport network - the designer will be at an advantage in their task when they are able to navigate and reconcile both the street and the bird's eye view perspectives. This becomes particularly apparent in the outcomes of technology uptake strategies and user acceptance tests.

Camacho and colleagues led a three year investigation into just this challenge (Camacho, Foth, \& Rakotonirainy, 2013). The immediate operational concerns that public transport service providers raise as crucial may include the efficiency and speed of services, different means to make timetable information available to passengers, reducing the waiting time, ensuring the service is safe to use by identifying hazards and reducing the risks of accidents, using CCTV systems and patrols to make carriages and stations safe for passengers, and providing value for money. However, when every one of these aspects runs smoothly, it may not make a notable difference to the service quality perceived by passengers, because that is often taken for granted. Negative or bad experiences register more prominently than normal or good performance, and bad experiences get reported in feedback channels more often than good ones (Baumeister, Bratslavsky, Finkenauer, \& Vohs, 200I). Therefore, there is a twofold argument here why granular and agile thinking matters.

First, a deep and rich understanding of public transport passengers and the types of activities and interactions they engage can make a difference to the range and quality of design solutions being considered. It also contributes to a better way of empathising with and responding to the diversity of passengers using the network and their specific circumstances, needs and requirements. In addition to needs and issues requiring attention, the designer can also use this street level understanding to perceive of the bus or train carriage as an "opportunity space" (Hornecker et al., 2006). This allows for the identification of design interventions and responses that the client may not have anticipated from their bird's eye view perspective but that may prove useful and appealing 
to increase the quality of a passenger's service experience (Camacho, Foth, Rakotonirainy, \& Rittenbruch, 2017/4).

Second, an urban interaction design approach that maintains a hybrid perspective of bird's eye and street view can be human- / user- / passenger-centric and still deliver and maintain the operational outcomes of the service provider. As this is not a question of 'either/or,' a hybrid approach may uncover new ideas and solutions that start as passenger-centric innovation, yet they may scale to give rise to new approaches and strategies for the future of public transport (Camacho, Foth, Rakotonirainy, Rittenbruch, \& Bunker, 2016). For example, public transport as an opportunity space has been explored to trial chat applications (Camacho, Foth, Rittenbruch, \& Rakotonirainy, 2015; Ti, 20I4), gamification (Toprak, Platt, Ho, \& Mueller, 20I3), music sharing (Bassoli, Brewer, Martin, Dourish, \& Mainwaring, 2007; Seeburger, Foth, \& Tjondronegoro, 2010), and other applications (Foth, Schroeter, \& Ti, 20I3).

Something we will explore in more detail later in this article, but worthwhile flagging now, is the consideration of decentering the human in the design, or here, decentering the passenger and their immediate perceived or reported needs of getting from $A$ to $B$ quickly. Such considerations may entail introducing design friction into the interaction or user experience (Cox, Gould, Cecchinato, lacovides, \& Renfree, 2016). It may produce novel, unusual and innovative results to experiment by diverting from the proven and often mission-critical pathway of a passenger-centric design approach, and then juxtapose and contrast these diverging designs. For example, there may be merit in journey planners "for getting lost" (Foth, 2016).

Serendipitor is part of the Sentient City Survival Kit (survival.sentientcity.net) (Shepard, $20 \mathrm{II}$ ). It is "an alternative navigation app for the iPhone that helps you find something by looking for something else" (serendipitor.net). Traunmueller's Likeways app provides alternative routing allowing users to lose themselves in their city and discover new parts of it by choosing routes that wander past restaurants, pubs, shops, museums, and art galleries (Traunmueller, Fatah gen. Schieck, Schöning, \& Brumby, 2013).

Stepping up from these first two levels of granularity that regard the user as city resident and consumer of city services, we will now look at users as participants in the city's community consultations and in that way explore how to increase agency over the planning, design and making of their urban environments.

\section{Participants}

There are many reasons that support the merits and benefits of getting users to participate in the design process, or more generally, for people to have a say in decisions that will affect them. In academia, action research has a long history advocating for not treating people as mere research subjects, but elevating their status to that of coinvestigator with a view to produce actionable knowledge and to bring about change for the better (Bradbury, 20I5). Reason (1998) provides a succinct account arguing corroborating the political, epistemological, ecological and spiritual dimensions of participation. In design, it is often not enough to subscribe to a human-centred or usercentred design approach, user participation is required at all stages of the design process. As a result, the field of Participatory Design (PD) has emerged focussing on questions, 
issues and challenges of how to go about user participation, considering different abilities and capacities to communicate and contribute, negotiating varying roles and agencies at play across different groups of stakeholders, and looking at different ways the domain expertise of the users can inform and become part of the design process in collaboration with users as co-designers (Foth \& Axup, 2006; Greenbaum \& Kyng, 1991; Schuler \& Namioka, 1993).

The shift in $\mathrm{HCl}$ from human factors to human actors to participatory design (Bannon, 1992; Greenbaum \& Kyng, 1991) resembles a similar development in urban planning in the 1980 s, which largely abandoned the representative practice of planning and embraced more participatory approaches that made community consultations a requirement (Laurian \& Shaw, 2009). It can be argued though that this shift was prepared by events and developments much earlier, one the most prominent of which was certainly the case of the Lower Manhattan Expressway in New York City in the 1960s. One of the main proponents of this ten lane highway was Robert Moses; one of the main opponents was Jane Jacobs, at the time chair of the "Joint Committee to Stop the Lower Manhattan Expressway." Zuckerman (201 I) reports that the "plans for the highway required the demolition of 14 blocks along Broome Street in Little Italy and Soho, and would have displaced roughly two thousand families and eight hundred businesses." Jacobs and her supporters not only defeated Moses and toppled the plans, she also wrote "The Death and Life of Great American Cities" (Jacobs, 196I), which Zuckerman (201I) calls "both a critique of 'rationalist' urban planning and a manifesto for preserving and designing vibrant urban communities."

An actual departure from the values and approaches taken by industrial city planners did not occur until the "communicative turn" in planning (P. Healey, 1996; Patsy Healey, 1992). Yet, to this date, planners often find themselves in a conflicted zone between - on the one side - the ideals of a participatory and communicative approach, which subscribes to values of dialogue, inclusion, tolerance and autonomy and listens to the community's voices. On the other side, there are the stark realities of the neoliberal, growth-oriented capitalist society that cities are situated within and that urban planners have to practice in (Sager, 2009). There are several advantages of a participatory practice of urban planning, including a broader range and more inclusive gathering of information to inform planning and the better chances of community acceptance when the plans reflect their needs and desires (Brody, Godschalk, \& Burby, 2003; Burby, 2003).

With participation becoming an imperative in both planning and design fields, it is not surprising that technology solutions quickly started to be developed in order to assist in community participation - from recruitment, consultation, feedback gathering, deliberation to codesign processes, and planning outcomes (Fredericks \& Foth, 2013; Houghton, Miller, \& Foth, 20I4; Wallin, Horelli, \& Saad-Sulonen, 2010). For example, Discussions in Space is a hybrid mobile phone and public screen application that allows passersby to contribute content via SMS or tweets (Schroeter \& Foth, 2009; Schroeter, Foth, \& Satchell, 20I2). It was originally conceived as a community engagement tool to help urban planners reach new participants, particularly those that were difficult to recruit using conventional community consultation methods. An extension of Discussions in Space that follows a hybrid (digital and physical) approach to situated community engagement is the InstaBooth (Caldwell \& Foth, 2017). Inspired by telephone booths in 
public urban space, the InstaBooth provides a portable structure that captures citizens' past stories and present opinions, particularly opinions regarding the future use and design of public space. The aim of the InstaBooth is to employ design approaches to engage local communities in a situated debate on the future of their urban environment. The Instabooth uses tangible and hybrid interaction such as multi-touch screens and media façades to facilitate face-to-face and digitally mediated discussions.

Houghton et al. (2014) distinguish between three categories of place-based technology in the context of urban planning, participatory urbanism, and urban interaction design:

I. Technology for analysis of place;

2. Technology to enhance people's experience in place;

3. Technology for community engagement about place.

In addition to the aforementioned examples that illustrate the third category, technology for community engagement about place, this section's focus on participation can relate to the other two categories as well. However, these first two categories often go beyond mere participation in that they allow an even higher level of agency, influence and involvement: users as co-creators.

\section{Co-Creators}

Examples of the first category defined by Houghton et al. (20l4), technology for analysis of place, have been studied and described by Paulos, Honicky, and Hooker (2009) as "Participatory Urbanism." Yet, here we are not talking about a city resident being given the chance to participate in a community consultation session and asked to provide feedback - usually at a time and place that suits the initiators of the consultation, the planner or the city. Here, we are referring to participation in the 'making of city' itself that re-conceptualises users as citizens (Foth, Tomitsch, Satchell, \& Haeusler, 20I5) and residents as co-creators in a collaborative approach to citymaking. In a citizen science effort, Paulos and his team attached environmental sensors to cabs and street sweepers in order to gather a more dynamic picture of air pollution in the city (Aoki et al., 2009). Data gathered from this project can give citizens (a) a better ability to argue the case for stronger urban policy responses to reduce traffic congestion and air pollution, and; (b) the chance to avoid polluted areas.

The field of media architecture has produced manifold cases of the second category defined by Houghton et al. (20l4), technology to enhance people's experience in place. What is specifically of interest to this section's focus on co-creation are those examples that are citizen-led, sometimes referred to as DIY urbanism (Finn, 20I4) or urban guerrilla movements (Caldwell \& Foth, 2014; Caldwell, Osborne, Mewburn, \& Crowther, 2015; Foth, Parra Agudelo, \& Palleis, 2013). Examples include graffiti (Iveson, 2010; Sliwa \& Cairns, 2007), parkour (Kidder, 2012), yarn bombing and guerrilla knitting (Wallace, 20I3), seed bombing and guerrilla gardening (Reynolds, 20I4), dîner en blanc (dinerenblanc.com), and Park(ing) Day (parkingday.org).

What these examples have in common is an emerging pattern of people actively involved in and often leading processes of change making. We can trace this changing role of people from consumers to producers, from stationary office workers to mobile urban nomads, from passive members of society to active instigators of change. It is therefore 
critical for urban interaction designers thinking and working at this level of conceptual granularity to reconsider whether the notion of 'user' requires not only an agile and temporary but perhaps a more lasting re-conceptualisation to that of 'citizen' (Foth, Tomitsch, et al., 2015). In turn, this begs the question how to translate (or add to) the well established set of design goals around usability. Could we conceive of 'citizen-ability' as an complementary goal for urban interaction designers to aspire to in order to create new civics for a better quality of life?

This discussion has a number of pertinent threads, many of which coalesce in Henri Lefebvre's concept of "le droit à la ville" (Lefebvre, 1996 [1968]), which has recently seen renewed interest with a view to adopt the original notion to contemporary questions of digital rights (Shaw \& Graham, 20I6) and the digital (or smart) city (Foth, Brynskov, \& Ojala, 20I5). Harvey (20I2, p. 4) argues that:

"The question of what kind of city we want cannot be divorced from that of what kind of people we want to be, what kinds of social relations we seek, what relations to nature we cherish, what style of life we desire, what aesthetic values we hold. The right to the city is, therefore, far more than a right of individual or group access to the resources that the city embodies: it is a right to change and reinvent the city more after our hearts' desire. It is, moreover, a collective rather than an individual right, since reinventing the city inevitably depends upon the exercise of a collective power over the processes of urbanization. The freedom to make and remake ourselves and our cities is, I want to argue, one of the most precious yet most neglected of our human rights. How best then to exercise that right"

While urban interaction design in pursuit of fostering participatory and do-it-yourself forms of urbanism is certainly valuable and commendable in its own right, it begs the question of scale and impact. Harvey's interpretation of Lefebvre's "right to the city" calls for new ways to change and reinvent the city. One possible argument interprets these micro-spatial and hyper-local urban practices as "urban acupuncture," that is, strategic local interventions that may trigger a wider and systemic effect on and across the city (Houghton, Foth, \& Miller, 20I5). However, another argument posits that for such DIY practices to generate implications for the city more broadly and into the future, there is a need to "assert new forms of authority in the city based on the equality of urban inhabitants" (Iveson, 2013, p. 94I).

What this new form of urban polity may look like is still open for discussion, debate, experimentation, and further research across different disciplines (Foth, Tomitsch, et al., 20I5). Schuler (20I3) employs civic intelligence in his vision for a "world citizen parliament." Current proponents of blockchain technology and distributed ledger systems propose new forms of distributed direct democracy comprising algorithmic and 'representativeless' government (Cicada, 2016). Initial steps in embracing more cocreative and collaborative efforts of citymaking certainly entail not only supporting the changing role of citizens, but also reconsidering the role of city administrations and local governments. As we stepped through the different levels of user granularity, we can in parallel trace a corresponding change in the identity and raison d'être of city governments from administrators, service providers, facilitator, to collaborators. At each step is it worthwhile to acknowledge that although this process is aggregative in that duties and obligations from the previous level continue, the quality of the relationship with the 
citizenry changes. There are similarities to the separation between researchers (city administration) and study subjects (residents) in positivist research approaches, which action research and other paradigms subscribed to an epistemological stance of social constructivism regard as counterproductive and replace with the notion of coinvestigators (co-creators).

There are established models such as private / public partnerships and triple helix innovation systems comprising government, business and academia (Foth \& Adkins, 2006) in order to forge the co-creative collaborations required to produce actionable knowledge and bring about change. However, there are still several challenges. First, there is a need to replace old ways of thinking in categories such as "top-down" and "bottom-up" - perhaps with "middle-out" (Fredericks, Caldwell, \& Tomitsch, 2016)? Second, new methodologies are required that are more inclusive with regards to the range of stakeholders able to be engaged, such as quadruple helix innovation systems that include government, industry, academia, and civil society (Leydesdorff, 20I2). And third, the increase in the number and diversity of stakeholders and partners presents new communication challenges. How do we ensure communication, interaction and deliberation occur in an inclusive, rational, effective, and productive manner? Even when well known challenges such as noise and equivocation are being addressed, do communicative processes often fall into either adversarial or consensual modes of deliberation. Dick argues to pay more attention to a third, that is, dialectic option, which he describes as "building agreement from disagreement" (Dick, 2002). It is useful to compare this approach with related approaches in interaction design, such as adversarial design (DiSalvo, 20I2) and agonistic design (Björgvinsson, Ehn, \& Hillgren, 20I0, 20I2). What appears to be missing as yet is an explicit entity in the quadruple helix comprising government, industry, academia, and civil society, that represents nature: Can we design for the cohabitation of cities and harmoniously live together with other living creatures? Conclusion: Towards Cohabitation

The final frontier (at least for this article) is to consider - alas briefly - ways society can engage in a socio-ecological transitioning towards a just and sustainable future (Fry, 2009). The aforementioned elaborations brought to the fore many challenges, two of which highlighted here by way of concluding: First, in the granular lineage of user from resident, consumer, participant to co-creator, there is a further step and an additional hurdle to take, which Forlano (2016) describes as "decentering the human in the design of collaborative cities." Removing humans as the exclusive inhabitants of the epicentre of design attention allows us to consider a more inclusive and encompassing worldview. This non- or post-anthropocentric perspective in design challenges us to re-think how usercentric design methods can become world-centric design methods (DiSalvo \& Lukens, 20II; Giaccardi, Cila, Speed, \& Caldwell, 2016; Giaccardi, Speed, Cila, \& Caldwell, 2016). It is a useful first step to expand the aforementioned quadruple helix to a quintuple or penta helix innovation model, which includes the natural environment (Calzada, 20 I3; Carayannis, Barth, \& Campbell, 2012), yet this is just the start of the socio-ecological transition humanity requires (Aiginger et al., 2016).

Second, the emerging practice of transition design (Irwin, 2015; Irwin, Kossoff, \& Tonkinwise, 2015) is particularly relevant in the context of cities and urban interaction design. In search of answers for how to transition humanity towards sustainable futures, it 
suffice to say that progressive, disruptive and radical change is required. The visions for this sustainable future vary: cosmopolitan localism (Manzini, 2009), beyond capital (Hakken, Teli, \& Andrews, 2015), voluntary simplicity and prosperous descent (Alexander, 2016), sustainment (Fry, 2003, 20II), mutualism (Jeremijenko, 2016), and cohabitation (N. Smith, Bardzell, \& Bardzell, 2017).

\section{References}

Amin, A. (2007). Re-thinking the urban social. City, I I I), I00-I I4.

Aiginger, K., Schratzenstaller, M., Leoni, T., Schaffartzik, A., Wiedenhofer, D., Fischer-Kowalski, M., ... Behrens, A. (2016). Europe's Path Towards the Socio-Ecological Transition. Intereconomics, 5 I (4), 184-I84.

Alexander, S. (2016). A Prosperous Descent: Telling New Stories as the Old Book Closes. Griffith Review, 52.

Aoki, P. M., Honicky, R. J., Mainwaring, A., Myers, C., Paulos, E., Subramanian, S., \& Woodruff, A. (2009). A vehicle for research: using street sweepers to explore the landscape of environmental community action. In Proceedings of the SIGCHI Conference on Human Factors in Computing Systems (pp. 375-384). ACM.

Bannon, L. (1992). From human factors to human actors: the role of psychology and humancomputer interaction studies in system design. In Design at work (pp. 25-44). L. Erlbaum Associates Inc.

Bassoli, A., Brewer, J., Martin, K., Dourish, P., \& Mainwaring, S. (2007). Underground Aesthetics: Rethinking Urban Computing. IEEE Pervasive Computing / IEEE Computer Society [and] IEEE Communications Society, 6(3), 39-45.

Baumeister, R. F., Bratslavsky, E., Finkenauer, C., \& Vohs, K. D. (200I). Bad is stronger than good. Review of General Psychology: Journal of Division I, of the American Psychological Association, 5(4), 323-370.

Beer, D., \& Burrows, R. (2007). Sociology and, of and in Web 2.0: Some Initial Considerations. Sociological Research Online, 12(5). Retrieved from http://www.socresonline.org.uk//2/5/I7.html

Bilandzic, M., \& Foth, M. (20I2). A review of locative media, mobile and embodied spatial interaction. International Journal of Human-Computer Studies, 70(I), 66-7I.

Björgvinsson, E., Ehn, P., \& Hillgren, P.-A. (2010). Participatory design and democratizing innovation. In Proceedings of the II th Biennial Participatory Design Conference (pp. 4I-50). ACM.

Björgvinsson, E., Ehn, P., \& Hillgren, P.-A. (20I2). Agonistic participatory design: working with marginalised social movements. CoDesign, 8(2-3), I27-I44.

Blomkvist, S. (2002). The User as a Personality-Using Personas as a Tool for Design. KTH-Royal Institute of Technology, Stockholm Www. Nada. Kth. Se/ tessy/Blomkvist. Pdf.

Bradbury, H. (20I5). The SAGE Handbook of Action Research. SAGE.

Brody, S. D., Godschalk, D. R., \& Burby, R. J. (2003). Mandating Citizen Participation in Plan Making: Six Strategic Planning Choices. Journal of the American Planning Association. American Planning Association, 69(3), 245-264.

Burby, R. J. (2003). Making Plans that Matter: Citizen Involvement and Government Action. Journal of the American Planning Association. American Planning Association, 69(I), 33-49.

Caldwell, G. A., \& Foth, M. (20I4). DIY media architecture: open and participatory approaches to community engagement. In Proceedings of the 2nd Media Architecture Biennale Conference: World Cities (PP. I-I0). ACM.

Caldwell, G. A., \& Foth, M. (20I7). Media Architecture: Using Information and Media as 
Construction Material. In A. Wiethoff \& H. Hussmann (Eds.), DIYIDIWO Media Architecture: The InstaBooth (pp. 6I-80). Walter de Gruyter GmbH \& Co KG.

Caldwell, G. A., Osborne, L., Mewburn, I., \& Crowther, P. (2015). Guerrillas in the [Urban] Midst: Developing and Using Creative Research Methods-Guerrilla Research Tactics. Journal of Urban Technology, 22(3), 2I-36.

Calzada, I. (20/3). Critical Social Innovation in the Smart City Era for a City-Regional European Horizon 2020. Retrieved from https://papers.ssrn.com/sol3/papers.cfm?abstract_id=2506952

Camacho, T., Foth, M., \& Rakotonirainy, A. (2013). Pervasive Technology and Public Transport: Opportunities Beyond Telematics. IEEE Pervasive Computing / IEEE Computer Society [and] IEEE Communications Society, I2(I), 18-25.

Camacho, T., Foth, M., Rakotonirainy, A., \& Rittenbruch, M. (2017/4). Understanding urban rail invehicle activities: An activity theory approach. Transportation Research. Part F, Traffic Psychology and Behaviour, 46, Part A, 70-86.

Camacho, T., Foth, M., Rakotonirainy, A., Rittenbruch, M., \& Bunker, J. (2016). The role of passenger-centric innovation in the future of public transport. Public Transport, 8(3), 453-475.

Camacho, T., Foth, M., Rittenbruch, M., \& Rakotonirainy, A. (2015). TrainYarn: Probing Perceptions of Social Space in Urban Commuter Trains. In Proceedings of the Annual Meeting of the Australian Special Interest Group for Computer Human Interaction (Pp. 455-464). ACM.

Carayannis, E. G., Barth, T. D., \& Campbell, D. F. J. (20I2). The Quintuple Helix innovation model: global warming as a challenge and driver for innovation. Journal of Innovation and Entrepreneurship, I(I), 2.

Cicada. (2016). Cicada: A Distributed Direct Democracy and Decentralized Application Platform. Retrieved from https://github.com/the-laughing-monkey/cicada-platform/blob/master/CicadaWhitePaper-2016-10.13.GA.I.pdf

Cox, A. L., Gould, S. J. J., Cecchinato, M. E., lacovides, I., \& Renfree, I. (2016). Design Frictions for Mindful Interactions: The Case for Microboundaries. In Proceedings of the $2016 \mathrm{CHI}$

Conference Extended Abstracts on Human Factors in Computing Systems (pp. 1389-1397). ACM.

Dick, B. (2002). Building agreement from disagreement: the anatomy of dialectical processes. Chapel Hill, QLD: Interchange.

DiSalvo, C. (2012). Adversarial Design. Cambridge, MA: MIT Press.

DiSalvo, C., \& Lukens, J. (20I I). Nonanthropocentrism and the Nonhuman in Design: Possibilities for Designing New Forms of Engagement with and through Technology. From Social Butterfly to Engaged Citizen: Urban Informatics, Social Media, Ubiquitous Computing, and Mobile Technology to Support Citizen Engagement, 42I.

Finn, D. (20I4). DIY urbanism: implications for cities. Journal of Urbanism: International Research on Placemaking and Urban Sustainability, 7(4), 38I-398.

Forlano, L. (2009). Codespaces: Community Wireless Networks and the Reconfiguration of Cities. In M. Foth (Ed.), Handbook of Research on Urban Informatics (pp. 292-309). IGI Global.

Forlano, L. (2016). Decentering the Human in the Design of Collaborative Cities. Design Issues, 32(3), 42-54.

Foth, M. (2016). Why we should design smart cities for getting lost. In J. Watson (Ed.), The Conversation Yearbook 2016: 50 Standout Articles from Australia's Top Thinkers (Pp. 109-I I3). Melbourne, Australia: Melbourne University Press.

Foth, M., \& Adkins, B. (2006). A Research Design to Build Effective Partnerships between City Planners, Developers, Government and Urban Neighbourhood Communities. The Journal of Community Informatics, 2(2). Retrieved from http://cijournal.net/index.php/ciej/article/viewArticle/292

Foth, M., \& Axup, J. (2006). Participatory Design and Action Research: Identical Twins or Synergetic Pair? Presented at the Participatory Design Conference (PDC), Trento, Italy. 
Foth, M., Brynskov, M., \& Ojala, T. (2015). Citizen's Right to the Digital City: Urban Interfaces, Activism, and Placemaking. Springer.

Foth, M., Forlano, L., Satchell, C., \& Gibbs, M. (20II). From Social Butterfly to Engaged Citizen: Urban Informatics, Social Media, Ubiquitous Computing, and Mobile Technology to Support Citizen Engagement. Cambridge, MA: MIT Press.

Foth, M., Parra Agudelo, L., \& Palleis, R. (20I3). Digital soapboxes: towards an interaction design agenda for situated civic innovation. In Proceedings of the 2013 ACM conference on Pervasive and ubiquitous computing adjunct publication (pp. 725-728). ACM.

Foth, M., Schroeter, R., \& Ti, J. (2013). Opportunities of Public Transport Experience Enhancements with Mobile Services and Urban Screens. International Journal of Ambient Computing and Intelligence (IJACl), 5(I), I-I8.

Foth, M., Tomitsch, M., Satchell, C., \& Haeusler, M. H. (20I5). From Users to Citizens: Some Thoughts on Designing for Polity and Civics. In Proceedings of the Annual Meeting of the Australian Special Interest Group for Computer Human Interaction (pp. 623-633). ACM.

Fredericks, J., Caldwell, G. A., \& Tomitsch, M. (2016). Middle-out design: collaborative community engagement in urban $\mathrm{HCl}$. In Proceedings of the 28th Australian Conference on Computer-Human Interaction (pp. 200-204). ACM.

Fredericks, J., \& Foth, M. (2013). Augmenting public participation: enhancing planning outcomes through the use of social media and web 2.0. Australian Planner, 50(3), 244-256.

Fry, T. (2003). The Dialectic of Sustainment. Design Philosophy Papers, I (5), 289-297.

Fry, T. (2009). Design Futuring: Sustainability, Ethics and New Practice. Bloomsbury Academic.

Fry, T. (20II). Time and the Political: Post-Urban Futures, Chronophobia and Unsettlement. Design Philosophy Papers, 9(2), 93-10I.

Giaccardi, E., Cila, N., Speed, C., \& Caldwell, M. (2016). Thing Ethnography: Doing Design Research with Non-Humans. In Proceedings of the 2016 ACM Conference on Designing Interactive Systems (pp. 377-387). ACM.

Giaccardi, E., Speed, C., Cila, N., \& Caldwell, M. L. (2016). Design Anthropological Futures. In R. C. Smith, K. T. Vangkilde, M. G. Kjærsgaard, T. Otto, J. Halse, \& T. Binder (Eds.), Things as Co-Ethnographers: Implications of a Thing Perspective for Design and Anthropology (pp. 235-248). Bloomsbury Academic.

Goffman, E. (2009). Relations in Public. Transaction Publishers.

Gordon, E., \& de Souza e Silva, A. (20I I). Net Locality: Why Location Matters in a Networked World. Chichester, UK: John Wiley \& Sons.

Graham, S. (2004). Beyond the "dazzling light": from dreams of transcendence to the "remediation" of urban life. New Media \& Society, 6(I), 16-25.

Greenbaum, J. M., \& Kyng, M. (199I). Design at Work: Cooperative Design of Computer Systems (pp. x, 294). Hillsdale, NJ: Lawrence Erlbaum Associates.

Guest, D. (|99|). The hunt is on for the Renaissance Man of computing. The Independent (London), 17.

Hakken, D., Teli, M., \& Andrews, B. (2015). Beyond Capital: Values, Commons, Computing, and the Search for a Viable Future. Routledge.

Hampton, K. N., Livio, O., \& Sessions, L. (2010). The Social Life of Wireless Urban Spaces: Internet Use, Social Networks, and the Public Realm. The Journal of Communication, 60(4), $701-722$.

Hardey, M. (2007). The city in the age of Web 2.0: A new synergistic relationship between place and people. Information, Communication and Society, 10(6), 867-884.

Harrison, S., Tatar, D., \& Sengers, P. (2007). The Three Paradigms of HCl. In Proceedings of CHI, alt.chi. New York: ACM.

Harvey, D. (2012). Rebel Cities: From the Right to the City to the Urban Revolution. Verso Books.

Healey, P. (1992). Planning through debate: the communicative turn in planning theory. The Town 
Planning Review, 63(2), 143.

Healey, P. (1996). The Communicative Turn in Planning Theory and its Implications for Spatial Strategy Formation. Environment and Planning. B, Planning \& Design, 23(2), 217-234.

Hearn, G., \& Foth, M. (2005). Action Research in the Design of New Media and ICT Systems. In K. Kwansah-Aidoo (Ed.), Topical Issues in Communications and Media Research (pp. 79-94). New York, NY: Nova Science.

Hearn, G., \& Foth, M. (2007). Communicative Ecologies: Editorial Preface. Electronic Journal of Communication, I 7(I-2). Retrieved from http://eprints.qut.edu.au/8I7//

Hornecker, E., Halloran, J., Fitzpatrick, G., Weal, M., Millard, D., Michaelides, D., ... De Roure, D. (2006). UbiComp in opportunity spaces: challenges for participatory design. In Proceedings of the ninth conference on Participatory design: Expanding boundaries in design - Volume I (pp. 4756). ACM.

Houghton, K., Foth, M., \& Miller, E. (20I5). Urban Acupuncture: Hybrid Social and Technological Practices for Hyperlocal Placemaking. Journal of Urban Technology, 22(3), 3-19.

Houghton, K., Miller, E., \& Foth, M. (20I4). Integrating ICT into the planning process: impacts, opportunities and challenges. Australian Planner, 5I(I), 24-33.

Huh, J., Ackerman, M. S., Erickson, T., Harrison, S., \& Sengers, P. (2007). Beyond usability: taking social, situational, cultural, and other contextual factors into account. In $\mathrm{CHI}$ '07 Extended Abstracts on Human Factors in Computing Systems (pP. 2II3-2। I6). ACM.

Irwin, T. (2015). Transition Design: A Proposal for a New Area of Design Practice, Study, and Research. Design and Culture, 7(2), 229-246.

Irwin, T., Kossoff, G., \& Tonkinwise, C. (20I5). Transition Design Provocation. Design Philosophy Papers, I3(I), 3-II.

Ishida, T., \& Isbister, K. (2000). Digital Cities: Technologies, Experiences, and Future Perspectives. In Lecture notes in computer science; 1 765. (Vol. LNCS I765, pp. ix, 444). Heidelberg, Germany: Springer.

Iveson, K. (20I0). The wars on graffiti and the new military urbanism. Cityscape , I4(I-2), I I5-I34.

Iveson, K. (20I3). Cities within the City: Do-It-Yourself Urbanism and the Right to the City. International Journal of Urban and Regional Research, 37(3), 94I-956.

Jacobs, J. (196I). The death and life of great American cities. New York: Vintage Books.

Jeremijenko, N. (2016). Creative Agency and the Space Race of the 2 Ist Century: Towards a Museum of Natural Futures. In Proceedings of the 2016 ACM Conference on Designing Interactive Systems (Pp. 3-4). ACM.

Kidder, J. L. (20I2). Parkour, The Affective Appropriation of Urban Space, and the Real/Virtual Dialectic. City \& Community, II (3), 229-253.

Kindberg, T., Chalmers, M., \& Paulos, E. (2007). Guest Editors' Introduction: Urban Computing. IEEE Pervasive Computing / IEEE Computer Society [and] IEEE Communications Society, 6(3), I820.

Laurian, L., \& Shaw, M. M. (2009). Evaluation of public participation: the practices of certified planners. Journal of Planning Education and Research, 28(3), 293-309.

Lefebvre, H. (1996). The right to the city. Writings on Cities, 63-I8I.

Leydesdorff, L. (20I2). The Triple Helix, Quadruple Helix, ..., and an N-Tuple of Helices: Explanatory Models for Analyzing the Knowledge-Based Economy? Journal of the Knowledge Economy, 3(I), 25-35.

Manzini, E. (2009). A cosmopolitan localism: Prospects for a sustainable local development and the possible role of design. In H. Clark \& D. Brody (Eds.), Design Studies: A Reader (p. 448). New York: Berg.

Milgram, S. (1992). The Individual in a Social World: Essays and Experiments. McGraw-Hill.

Monk, A., \& Howard, S. (1998). The Rich Picture: A Tool for Reasoning About Work Context. 
ACM SIGCHI Interactions, 5(2), $21-30$.

Paulos, E., \& Goodman, E. (2004). The familiar stranger: anxiety, comfort, and play in public places. In Proceedings of the SIGCHI Conference on Human Factors in Computing Systems (pp. 223-230). ACM.

Paulos, E., Honicky, R. J., \& Hooker, B. (2009). Citizen Science: Enabling Participatory Urbanism. In M. Foth (Ed.), Handbook of Research on Urban Informatics: The Practice and Promise of the RealTime City (pp. 4I4-436). Hershey, PA: IGI Global.

Reason, P. (1998). Political, Epistemological, Ecological and Spiritual Dimensions of Participation. Studies in Cultures, Organizations and Societies, 4(2), 147-167.

Reynolds, R. (20I4). On Guerrilla Gardening: A Handbook for Gardening without Boundaries. Bloomsbury Publishing.

Rogers, Y. (2009). The Changing Face of Human-Computer Interaction in the Age of Ubiquitous Computing. In A. Holzinger \& K. Miesenberger (Eds.), $\mathrm{HCl}$ and Usability for e-Inclusion (Vol. 5889, pp. I-19). Berlin, Heidelberg: Springer Berlin Heidelberg.

Sager, T. (2009). Planners' Role: Torn between Dialogical Ideals and Neo-liberal Realities. European Planning Studies, I 7(I), 65-84.

Scharl, A., \& Tochtermann, K. (2007). The geospatial web how geobrowsers, social software and the Web 2.0 are shaping the network society. London: Springer.

Schroeter, R., \& Foth, M. (2009). Discussions in space. In Proceedings of the 2 Ist Annual Conference of the Australian Computer-Human Interaction Special Interest Group: Design: Open 24/7 (pp. 38I384). ACM.

Schroeter, R., Foth, M., \& Satchell, C. (20I2). People, content, location: sweet spotting urban screens for situated engagement. In Proceedings of the Designing Interactive Systems Conference (pp. 146-I55). ACM.

Schuler, D. (20I3). Creating the world citizen parliament: seven challenges for interaction designers. Interactions, 20(3), 38-47.

Schuler, D., \& Namioka, A. (1993). Participatory Design: Principles and Practices (p. xiii, 319 p.). Hillsdale, NJ: Lawrence Erlbaum.

Seeburger, J., Foth, M., \& Tjondronegoro, D. (2010). Capital music: personal expression with a public display of song choice. In Proceedings of the 6th Nordic Conference on Human-Computer Interaction: Extending Boundaries (PP. 777-780). ACM.

Seeburger, J., Foth, M., \& Tjondronegoro, D. (2015). Digital Design Interventions for Creating New Presentations of Self in Public Urban Places. In M. Foth, M. Brynskov, \& T. Ojala (Eds.), Citizen's Right to the Digital City (pp. 3-2I). Springer Singapore.

Shaw, J., \& Graham, M. (Eds.). (2016). Our Digital Rights to the City. Meatspace Press.

Shepard, M. (20I I). Sentient City: Ubiquitous Computing, Architecture, and the Future of Urban Space. Cambridge, MA: MIT Press.

Shklovski, I., \& Chang, M. F. (2006). Guest Editors' Introduction: Urban Computing--Navigating Space and Context. Computer, 39(9), 36-37.

Sliwa, M., \& Cairns, G. (2007). Exploring Narratives and Antenarratives of Graffiti Artists: Beyond Dichotomies of Commitment and Detachment. Culture and Organization, I3(I), 73-82.

Smith, N., Bardzell, S., \& Bardzell, J. (2017). Designing for Cohabitation: Naturecultures, Hybrids, and Decentering the Human in Design. In Proceedings of the 35th Annual ACM Conference on Human Factors in Computing Systems. Denver, CO: ACM.

Ti, J. T. H. (20I4). Urban Informatics and Public Transport. In N. Gardner, M. H. Haeusler, \& B. Mahar (Eds.), INTERchanging: Future Scenarios for Responsive Transport Infrastructure Design (PP. 9I-95). Baunach, Germany: Spurbuchverlag.

Toprak, C., Platt, J., Ho, H. Y., \& Mueller, F. (20I3). Cart-load-o-fun: designing digital games for trams. In CHI 'I3 Extended Abstracts on Human Factors in Computing Systems (pp. 2877-2878). ACM. 
Traunmueller, M., Fatah gen. Schieck, A., Schöning, J., \& Brumby, D. P. (20/3). The path is the reward: considering social networks to contribute to the pleasure of urban strolling. In $\mathrm{CHI}$ 'I 3 Extended Abstracts on Human Factors in Computing Systems (pp. 919-924). ACM.

Wallace, J. (20I3). Yarn bombing, knit graffiti and underground brigades: a study of craftivism and mobility. Journal of Mobile Media: Sound Moves, 7(I).

Wallin, S., Horelli, L., \& Saad-Sulonen, J. (2010). Digital Tools in Participatory Planning. Espoo, Finland: Centre for Urban and Regional Studies, Aalto University.

Whyte, W. H. (1980). The social life of small urban spaces.

Ylipulli, J., Suopajärvi, T., Ojala, T., Kostakos, V., \& Kukka, H. (20I4). Municipal WiFi and interactive displays: Appropriation of new technologies in public urban spaces. Technological Forecasting and Social Change, 89, I45-160.

Zuckerman, E. (201 I). Desparately Seeking Serendipity. In Proceedings of the SIGCHI Conference on Human Factors in Computing Systems. ACM. https://doi.org/I0.1 I45//978942.2 167/83. 